\title{
Buildings and Architecture
}

\section{Air Conditioning}

Dehumidification equipment employing triethylene glycol $\left[\left(\mathrm{HOCH}_{2} \mathrm{CH}_{2} \mathrm{OCH}_{2}\right)_{2}\right]$ as the dehumidifying agent, was announced jointly by Research Corporation, New York, and the Rogers Diesel \& Aircraft Corporation, New York, at a meeting held Dec. I7, 1945. The system was developed by the former company, a nonprofit organization, which has licensed Rogers Diesel \& Aircraft Corporation commercially to exploit the apparatus developed to carry out the cycle. The system which has been named the Rogers-Research system of air conditioning, has, in addition to the dehumidifying function, a second feature -that of sterilizing the air. This results from the introduction into the air stream of minute portions of triethylene glycol which has important antiseptic properties. It is applicable to industrial and comfort air conditioning.

The description of this system is contained in an article, "Dehumidifying and Air Sterilization with Triethylene Glycol," appearing in the January 1946 issue of Heating and Ventilating, p. 78-80. Librarians should find this article helpful.

\section{Notes on Partition Costs}

$I^{N}$ $N$ ORDER to secure the kind of internal flexibility that librarians consider necessary to permit them to adapt their libraries to changing needs, much attention has been focused on movable prefabricated panel partitions. Such partitions made of steel, glass, asbestos, and other materials have long been on the market and have been manufactured by more than a dozen large reliable manufacturers.

The question of the costs of these partitions as compared with the standard hollow tile and plaster partition is one to which librarians are seeking an answer.

In order to make a fair comparison between these two types of partitions, it is necessary to take into consideration the following factors: the original cost of installation, the comparative costs of moving and changing, acoustical qualities, appearance, maintenance, and accessibility to building services such as electrical and communication outlets.

Mr. Long, superintendent of the Bell Telephone Laboratories, made the statement to a group of librarians and architects last spring that the original cost of the steel partitions used in the Bell Laboratories was higher than tile and plaster partitions, but that if a partition were moved only once, the steel partition would pay for itself. Furthermore, he said that the partitions used there could be altered without any interference with the work of the area concerned, which in his judgment was an important factor that could not be measured in terms of dollars and cents.

Another bit of evidence on this question can be found in a chart in Sweet's File-Architectural 1945 in the Hauserman catalog, p. 8. This is found in section I9-A. This chart also compares types of partitions in terms of erection time in days and tear-down time in days.

The essential fact shown in this chart is that the "master walls" made of steel or glass are approximately 40 per cent more expensive than tile and plaster partitions as a first cost but that at the end of ten years' time, in terms of maintenance alone, the costs are equalized. If the partitions are moved once, the master walls are 30 per cent less expensive than tile and plaster. If they are moved twice, they are 60 per cent less expensive, and if they are moved three times, they are approximately 90 per cent less expensive.

These figures are, of course, those of one manufacturer and should be interpreted as such. Even so, they provide an interesting analysis of partition costs. 


\section{Fluorescent Light and Eye Trouble}

The Pencil Points, Progressive Architecture, for September 1945, page 98, carries a brief statement refuting the rumors that fluorescent lights are harmful to eyes. The basis for the statement lies in the work of Dr. Matthew Luckiesh and Mr. A. H. Taylor, light scientists from General Electric's lighting research laboratory.

The statement, which is merely a summary of a report published elsewhere, discusses the problem in terms of the effects of ultra violet, infrared, and visible radiant energy.

Every librarian concerned with the lighting problem should read this statement and draw his own conclusions. The essence of the report is, "If fluorescent light itself is bad for your eyes, so are incandescent, electric, gas, and candle light-and even natural sky light."

\section{Mold Preventive for Bookbindings}

T N WARM CLIMATES following a protracted 1 rainy spell, it is not uncommon to find one's bookbindings supporting a heavy growth of mold, which if unchecked will disfigure the books. Mere dusting removes the superficial growth without disturbing the mold actually growing in the paste of the bindings.

Several years ago, following a wet season, the Duke Hospital Library had an epidemic of mold in two stacks of bound journals which stood near an underground ventilator drawing air from an open areaway. The author was called upon for suggestions to remedy the situation. The vent was closed and the following solution was wiped over the molded bindings:

$\begin{array}{lr}\text { Thymol crystals } & \text { Io grams } \\ \text { Mercuric bichloride } & 4 \text { grams } \\ \text { Ether } & 200 \mathrm{cc} \\ \text { Benzene } & 400 \mathrm{cc}\end{array}$

The treated volumes have never shown any tendency to mold since and any other outbreaks of mold have been similarly and effectively treated. The solution is poison- ous and inflammable and should be used carefully in an open room or outdoors with no source of fire near by. It is best applied with a cotton sponge tied to a suitable applicator or held by forceps, so that none of it gets upon the fingers. The solution penetrates the bindings readily and dries rapidly, leaving no precipitate. One application is usually sufficient and the books may be returned at once to their places. It is wise to test first one corner of the binding before using the solution to discover whether the dye may run or change in any way. In our experience it has not altered the appearance of the goods nor affected the letter stampings.

The solution may, as well, be safely used on record album backs, leather boxes, and luggage, but it should never be used on any wearing apparel.

Duncan C. Hetherington

Department of Anatomy, Duke University School of Medicine, Durham, N.C.

Reprinted, with permission from the author, from Science, vol. Iо1, no. 2618, p. 223, Mar. 2, 1945 . 


\section{Personnel}

$\mathrm{O}$ TTO Kin KeldeY, librarian and musicologist, has retired from his posts at Cornell University. Happily, the news comes simultaneously that he will continue his teaching in other universities. And so there closes only a part of the career of one of the figures of

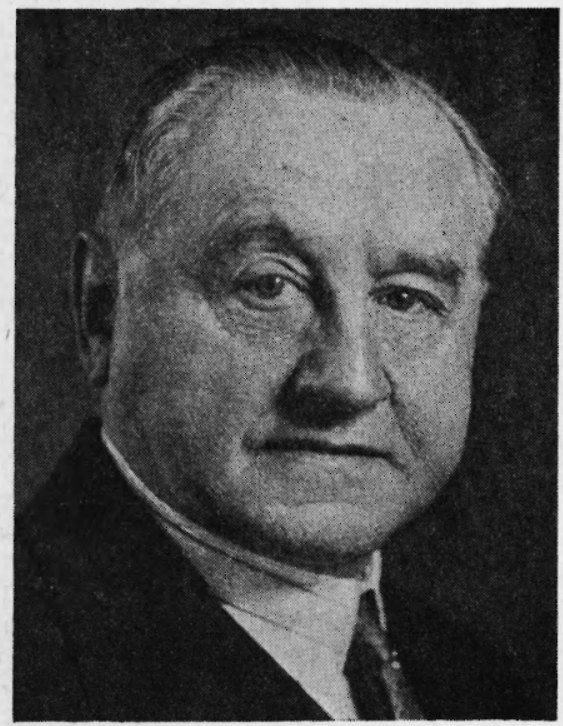

Otto Kinkeldey

whom the world of learning in America can be most proud.

Born in New York on Nov. 27, I878, Dr. Kinkeldey studied at the College of the City of New York (A.B., I898), New York University (A.M., I900), and at Columbia with Edward MacDowell. From I902 until the outbreak of the First World War he was in Germany, first as a student in the University of Berlin (Ph.D., I I09) and later as professor of musicology at the University of Breslau -an appointment of remarkable and probably unexampled honor for an Ausländer in his early thirties.

On his return to this country, Dr. Kinkeldey became chief of the Music Division of the New York Public Library, a post he held until 1930, except for two absences: in 1917I9 as captain of infantry in the United States Army and in 1923-27 as professor of music at
Cornell. In 1930 he was recalled to Cornell as university librarian and professor of musicology. This was the first appointment to a chair in this subject in the United States.

To those who think of him principally as the librarian of a great university, Dr. Kinkeldey's contribution to musical scholarship may to some extent be unknown. He studied in Berlin at a time of great activity in historical and scientific studies in music and in the company of a brilliant generation of German scholars. In that company, even though a foreigner, he won an immediate place with his dissertation Orgel und Klavier in der Musik des I6. Jahrhunderts, which, published in fuller form in 1910, established and maintained for him an international reputation. It opened up a new area of music history and is still the standard work on its subject. Like all his later writings, it is characterized by meticulous scholarship and artistic sensibility and is grounded in broad learning.

Dr. Kinkeldey's career spans the period of the origin and growth of research work in music in this country and its gradual admission to the realm of scholarship. With Oscar Sonneck and one or two others, he was a leader and a personification of this development. Uniting in himself the best elements of the culture of America and of Europe, he was able to give the European tradition of musical scholarship a native place in our intellectual life. This achievement is due not only to his profound musical learning but also, and perhaps the more, to his very remarkable knowledge of other fields.

Dr. Kinkeldey's professional life has given fruitful expression to his two great interests, music and books. His first achievement in this country was the development of the music collection of the New York Public Library to one of international importance, with a place in this country second only to that of the Library of Congress. In search of materials he went twice to Europe, in I92I-22 and again in 1928 for the sale of the great Wolffheim collection in Berlin, at which he was acknowledged by Europeans to be the most careful and discriminating buyer. 
It was eminently fitting that the first university professorship in musicology in the United States was offered to Otto Kinkeldey. It was in his Cornell seminar and in his summer classes at Harvard that he brought the wealth of his learning to a generation of young American scholars, inspiring them with the knowledge he imparted and furnishing them with a model for the furthering of historical scholarship in music throughout the country. Fortunately this work will go on in lectures and classes at Michigan and Harvard in the coming academic year.

In professional matters Dr. Kinkeldey has been active in fields of his own choosing. He was a prime mover in the establishment of two organizations and the first president of both - the Music Library Association (I93I) and the American Musicological Society (1934). $\mathrm{He}$ has been assiduous in attendance at the meetings of the Association of Research Libraries and the Conference of Eastern College Librarians and is an active member of the Bibliographical Society of America. He has frequently served the American Council of Learned Societies as a member of its Committee on Musicology.

If one seeks the man in his style, Dr. Kinkeldey's writings will be rewarding. He is master of an English prose of precision, flexibility, and color. His thought is both precise and expansive, his exposition fluent, his metaphors and allusions of illuminating appropriateness. It may be a paper on American higher music education (proceedings of the Music Teachers National Association, 1934), an article on Schubert's dances (Musical Quarterly, 1928), a paragraph on the new wing of the Cornell library (his Report for I937-38), a chapter on palm-leaf books (William Warner Bishop memorial volume, I94I), or his definition of musicology (International Cyclopedia of Music and Musicians, 1939)in all of them the learning is profound, the thought clear, the expression memorable.

In the plane in which scholars and librarians move, the circle of fame has a narrow radius. Otto Kinkeldey is the kind of man who does not seek to extend the length of his. He does not write in order to get into print. He does not speak in order to command an audience. Established in his mind, with the unawareness of self that excludes both pride and undignified modesty, he has been spared the pains of proving his worth to others. It is secure.-Richard S. Angell.

$\mathrm{O}$ N SePt. I, 1946, Stephen A. McCarthy moves to Cornell University where he succeeds Dr. Otto Kinkeldey as director of the library.

Readers of College and Research Libraries were acquainted, in the June 1944 issue, with the newly created post Dr. McCarthy now

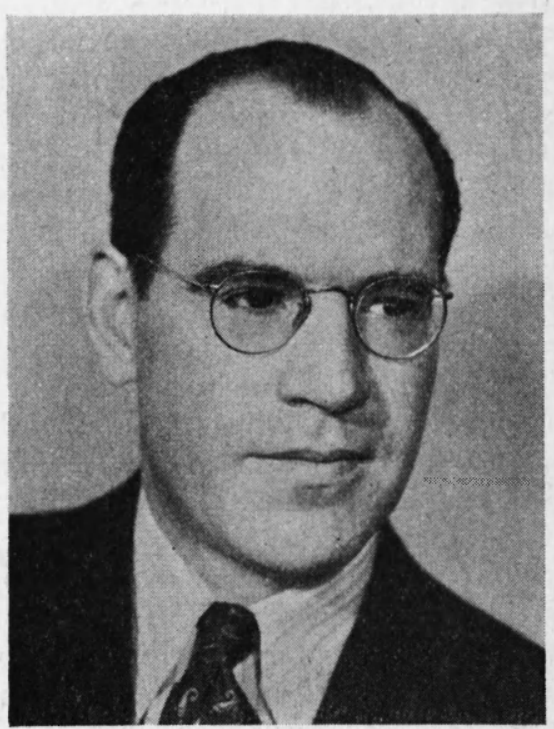

Stephen A. McCarthy

relinquishes at Columbia University. As one of three assistant directors of coordinate rank, he has been in charge, under the director of libraries, of certain functions of general administration-personnel, budget preparation and control, relations with the general public, management of the library office, and management of the physical plant. During Dr. McCarthy's period of service at Columbia the responsibilities of this post have been especially heavy. In the first place, the director of libraries was on leave in 1944-45. Added responsibilities fell on all of the assistant directors as a result; but Dr. McCarthy was the senior assistant director and in that capacity took final responsibility for decisions made on behalf of the director of libraries. In the second place, the shortage of manpower for libraries from 1944 to 1946 has been acute, as all whose battle stations were along the 
home front well know. Dr. McCarthy is the one who stood in the gap, with department heads at Columbia, and did most to keep readers' and technical services unimpaired in spite of unprecedented turnover in staff.

Probably the best brief description which can be given of Dr. McCarthy's work at Columbia is to say that he made a new position. It existed merely on paper when he accepted it. It is a position for which some would have been temperamentally unsuited because it fell too far to one side of the limelight. It is a position comparable in many respects to that of the player in the backfield whose duty is to run interference for his teammates; and in one case, as in the other, those who know the game know how much the score depends upon such unselfish, dependable performance.

Dr. McCarthy is a man of strength and firm resolution. His position, if not spectacular, has nevertheless been one of responsibility, and, in filling it, he has shown uncommon administrative ability. He has unsnarled tangled problems ranging from strings tied around prospective gifts to clarifying such difficult questions as who belongs to the clientele of the Columbia University $\mathrm{Li}$ braries. $\mathrm{He}$ has worked intelligently toward improving personnel management in the libraries. He has served on important university committees. In all of these things, he has consistently put the welfare of the libraries and of the university ahead of his personal interests. In his conversations about the work of the libraries, the first person personal pronoun never obtruded itself.

$\mathrm{He}$ will be remembered at Columbia as a man of marked administrative power and as a colleague who enjoys and who inspires good teamwork.-C.M.W.

To appointing Benjamin E. Powell as 1 director of libraries, Duke University brings back to the campus one of her own graduates and a former member of the library staff.

Mr. Powell was graduated from Duke in 1926. Following a year of high school teaching and two years in the circulation department of the Duke University Library, he began work for his library degree, which he received from the School of Library Service of Columbia University in I930. Four years

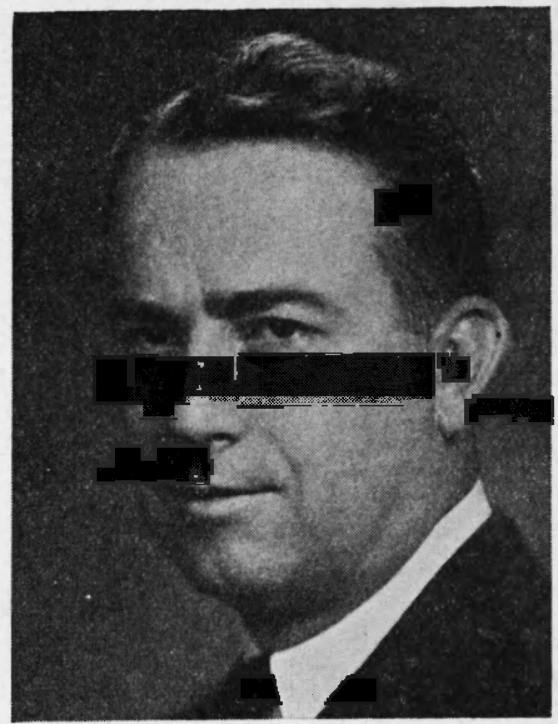

Benjamin E. Powell

later he entered the Graduate Library School at Chicago, where he has completed the residence requirements for the Ph.D.

After graduation from Columbia $\mathrm{Mr}$. Powell returned to Duke as chief of the reference and circulation division, a position he held from 1930 to 1937 . In that year he became librarian of the University of Missouri. Possibly his most important single contribution at Missouri lay in the truly notable progress which was achieved during these seven years in the development of the library's book collections. Hardly , less conspicuous was the growth of staff and staff esprit de corps under Mr. Powell's administration.

Mr. Powell has been active in the Missouri Library Association, of which he was president from 1938-39; the Association of College and Reference Libraries, of which he was secretary from $194 \mathrm{I}-44$; and in the American Library Association and the Columbia, Mo., Library Club. $\mathrm{He}$ has been a contributor of articles to School and Society, College and Research Libraries, and the Missouri Library Association Quarterly.

Those who know Mr. Powell as a librarian only are unfortunate; he was a crack miler in his undergraduate days, and the writer of these lines can testify that, as late as 1935, he was a nasty opponent on the handball court. The editor of these notes has forbidden 
mention of any of Mr. Powell's further and, in our opinion, more interesting nonprofessional activities.-J. Periam Danton.

Richard S. Angell, the new chief of the R Copyright Cataloging Division of the Library of Congress, was graduated from Princeton in 1927 and studied musicology at Harvard, where he was awarded his A.M. in 1933. After study at the School of Library

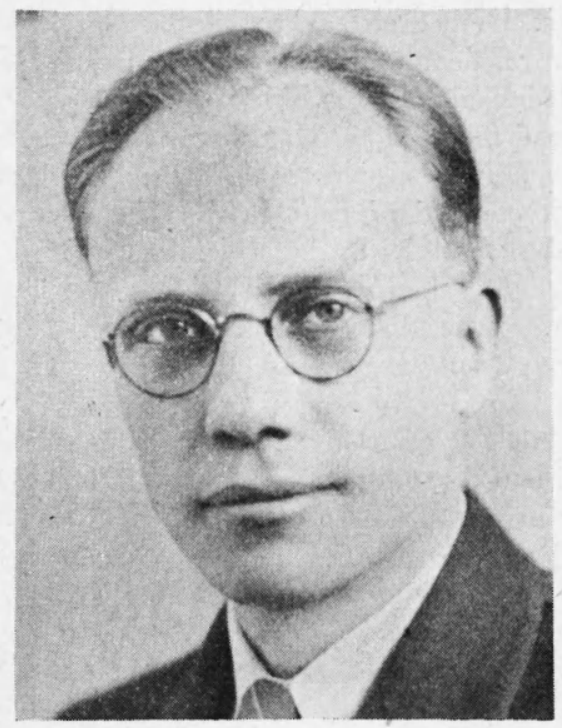

Richard S. Angell

Service at Columbia, Mr. Angell was made cataloger of Columbia's music library and, in 1935, its librarian. In 1942 he became assistant professor in the School of Library Service. Mr. Angell has taught courses in music library administration and music bibliography in the library school and in the department of music. In $1944-45$ he served as acting chief of the music division of the Reference Department of the New York Public Library.

Mr. Angell was awarded a Guggenheim fellowship in 1945 to prepare a book on music library administration, which will be published in 1947. He is a member of the Music Library Association and the American Musicological Society and has served as a member of the executive committee of the National Music Council. He was a leader in a movement to establish professional standards for music librarianship and for the adoption of a code for music cataloging.

Although Mr. Angell will continue to be interested in music bibliography, his new appointment represents a departure from music librarianship. The Copyright Cataloging Division of the Library of Congress includes four departments, of which one processes music. The division is endeavoring to increase the usefulness of its catalogs to scholars, librarians, and other interested groups; to this end, the division solicits the advice of trade and professional groups. The work of the division and the special problems of its music catalog were discussed at a recent meeting of the Music Library Association held in Washington.-Andrew K. Peters.

$\mathrm{R}^{2}$ AYNARD C. Swank assumed the duties of university librarian at the University of Oregon on July I, 1946. In this position he succeeds Matthew Hale Douglass who retired in 1942 after thirty-four years of service at the university. Dr. Swank goes to Oregon from the University of Minnesota,

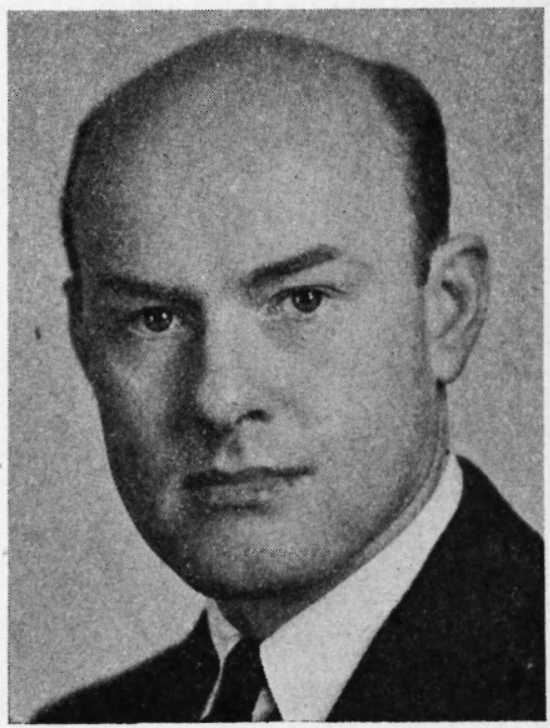

Raynard C. Swank

where he has been chief catalog librarian and assistant professor of library science.

Dr. Swank is a graduate of the College of Wooster and took his first year of library training at Western Reserve University, graduating in 1937. The next four years 
were spent at the University of Colorado as junior cataloger, then as documents and serials librarian, and finally as documents librarian. In the last capacity he organized the present documents division in Colorado's new library building and devised a classification scheme, later published in Special Libraries, for state, county, and municipal documents.

In I94I Dr. Swank enrolled as a fellow in the Graduate Library School, University of Chicago, where he specialized in bibliography and cataloging in the university library field. $\mathrm{He}$ was granted the Ph.D. degree in June 1944, his dissertation being The Organization of Library Materials for Research in English Literature.

After a summer as bibliographer in the University of Chicago Libraries, he went to the University of Minnesota as visiting lecturer and later as assistant professor in the division of library instruction, where he taught courses in cataloging and classification. Since July 1945, while still teaching part time, he has been head of the catalog department of the University of Minnesota Library.

$\mathrm{T}$ he Selection of Robert H. Deily as head of the Department of Library Science of the University of Kentucky has been announced by President Donovan. Dr. Deily, recently discharged from the Army

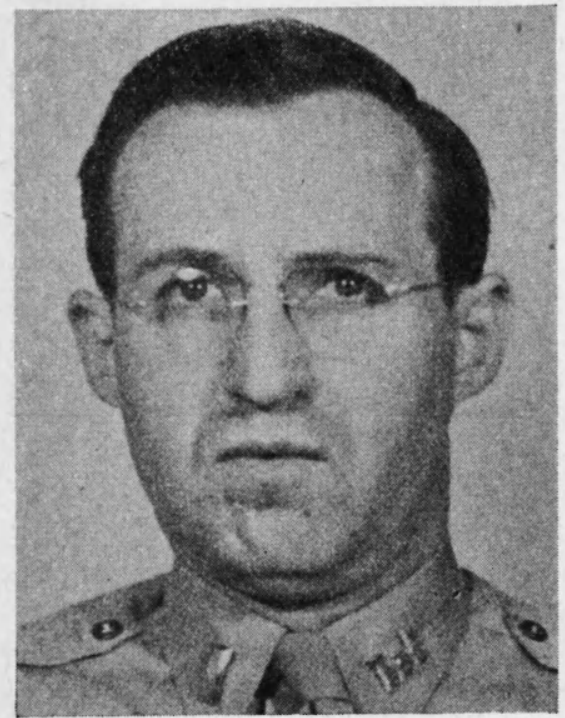

Robert H. Deily after almost four years of service, will assume his new duties in July. Much of Dr. Deily's Army career was spent with the Manhattan Engineering District, commonly known as the atom bomb project. He was assigned to the district as assistant to the district intelligence officer, with station at the Los Alamos Experimental Laboratory near Santa Fe, N.M. Since December he has been detailed to duty at the main production plant at Oak Ridge, Tenn.

Dr. Deily returns to the academic scene after residency on several campuses. $\mathrm{He}$ attended Muhlenberg College as an undergraduate and received an M.A. in English literature from Lehigh University. At Columbia University School of Library Service he received the B.S. and M.S. degrees. In 1939 he was awarded a University of Chicago fellowship and in I94I was graduated with the Ph.D. degree from the Graduate Library School, with a major in administration.

His first positions were part-time ones at Muhlenberg College and Lehigh University, and in the Reference Division of the New York Public Library. After a year of cataloging experience and a year in the reference department at Lehigh he became librarian of Wagner College at Staten Island, N.Y. After three years there he went to the Brooklyn Public Library and secured further training by working a year in the book order department and a year as a branch librarian in that system.

At Kentucky Dr. Deily wishes to experiment with the basic first-year library school program as a part of the regular four-year undergraduate course. It is his belief that this method should help fill existing library vacancies more rapidly, provide earlier earning power, and lower the educational costs to the student.

DWard B. Stanford, recently appointed E assistant university librarian and assistant professor at the University of Minnesota, now returns to librarianship from service in the armed forces overseas. A graduate of Dartmouth College, where he majored in biography and comparative literature, Dr. Stanford obtained his first professional experience in the library of his alma mater and later served on the staffs of the Detroit Public Library and the library at Williams College. 


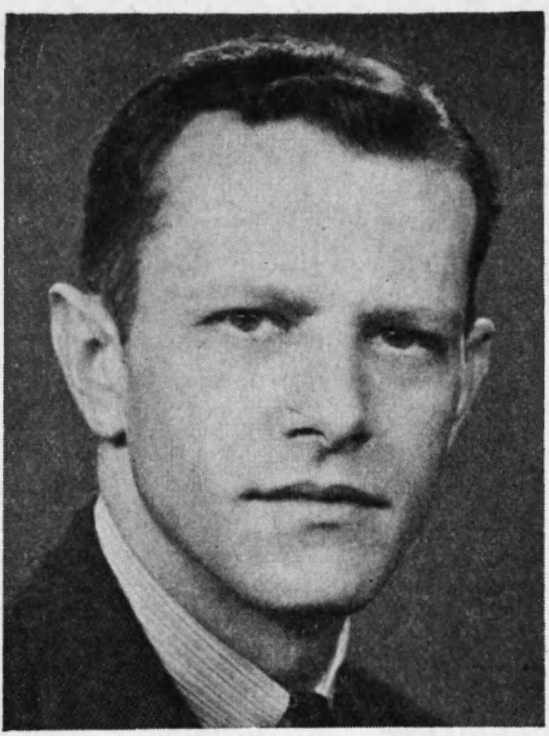

Edward B. Stanford

In 1934-35 Dr. Stanford served at A.L.A. Headquarters as editorial assistant on the A.L.A. Bulletin. Later, as senior assistant at Williams, he developed the freshman orientation program for the college and made a study of college library handbooks while preparing one for the use of local undergraduates. Also, while at Williams, Dr. Stanford obtained his M.A. degree in English literature.

In 1939 Dr. Stanford was awarded an A.L.A. fellowship grant from the Carnegie Corporation to study the effect of honors work and independent study programs on library service in liberal arts colleges, at the Graduate Library School of the University of Chicago. The findings of this study were reported in the Library Quarterly in 1942. His Library Extension under the W.P.A.: An Appraisal of an Experiment in Federal Aid (University of Chicago Press, 1944), presents an evaluation of the techniques employed in conducting area-wide demonstrations of library service with the assistance of federal work relief funds during the years 'of the depression.

Early in 1943 Dr. Stanford shipped as an Army classification specialist to England, where he was in charge of the reclassification of combat casualties to "limited assignment" occupations. Later he was called to Paris to help organize the library instruction program for the E.T.O. V-E Day found Dr. Stanford teaching in the information-education officer's staff school at Shrivenham, near Oxford; and shortly thereafter he became responsible for establishing unit libraries in the redeployment camps throughout southern England.

As a result of his experience with the Army library program overseas, Dr. Stanford feels that publishers and librarians alike would learn much from a thoroughgoing study of the reading and library services provided for military personnel in World War II.

Torman L. Kilpatrick has recently been appointed to the staff of the State University of Iowa Libraries as associate director in charge of technical processes.

Mr. Kilpatrick came to the State University of Iowa from the Department of Agriculture

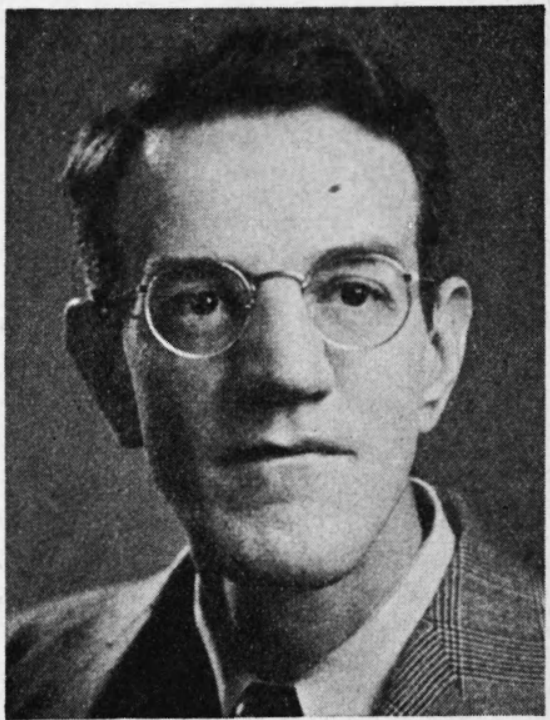

Norman L. Kilpatrick

Library in Washington, D.C. At the Department of Agriculture he was chief of the acquisition section and assisted the librarian to develop work standards and simplify procedures for performing the various jobs connected with order, exchange, and serial checking.

Before becoming a member of the U.S. Department of Agriculture staff, Mr. Kilpatrick was chief of the preparations division at Brown University. In this capacity he effected a reorganization of the catalog department and synchronized the work of the 
technical processes to meet the needs of the library when it was reorganized on a divisional basis.

While at Brown he was granted a year's leave of absence to organize the survey of federal archives in Rhode Island and Connecticut.

Mr. Kilpatrick received his A.B. from Brown University in 1928 and, upon graduation, was appointed instructor in English and Latin at the Sofia American College in Sofia,
Bulgaria. After two years of teaching and traveling abroad, he returned to Brown for graduate study and was awarded an A.M. in the field of history in 1932. In 1940 he received his B.S. in Library Service from Columbia University.

$\mathrm{He}$ has held several offices in the Rhode Island Library Association and served as president of that association from 1938 to 1940. He is the author of several professional articles.-Ralph E. Ellsworth.

\section{Appointments}

$\mathrm{J}$ oHN VANMale, librarian of the University of South Carolina, will join the staff of the University of Denver on August Io as librarian of the Mary Reed Library and assistant director of libraries of the university.

Kenneth R. Shaffer, executive director of the American Book Center for War Devastated Libraries, has been appointed director of the School of Library Science at Simmons College, Boston.

Albert C. Gerould, librarian of the College of the Pacific, Stockton, Calif., has been appointed assistant librarian of the United Nations in New York City.

Richard H. Logsdon, recently released from the Navy, is now chief librarian of the U.S. Office of Education in Washington. Dr. Logsdon has been head of the Library Science Department of the University of Kentucky at Lexington.

James G. Van Derpool, head of the art department of the University of Illinois, has been appointed librarian of the Avery Library of Architecture at Columbia University and has been given a seat on the faculties of architecture and library service.

Wayne S. Yenawine, until recently acting director of libraries of the University of Georgia, is now librarian of the new Air University at Maxwell Field, Ala.

Luis E. Bejarano, who has been with the training division of the United States Naval Reserve, has been appointed chief librarian of the United States Merchant Marine Academy, Kings Point, N.Y.

Andrew K. Peters, librarian of the Journalism Library of Columbia University, has been appointed university librarian of St. Lawrence University, Canton, N.Y.

Catherine Keyes Miller has been appointed music librarian of Columbia University and instructor in library service of the School of Library Service, Columbia University.

Clara T. Heck has been appointed librarian of the reference department of the Army Medical Library, Washington, D.C.

Lydia M. Gooding, acting librarian of Mount Holyoke College since 1944, has been appointed librarian of Pembroke College, Brown University, Providence.

Edward C. Heintz has been appointed assistant librarian of Bowdoin College, Brunswick, Me.

Mrs. Dorothy Flower Livingston, research assistant and reviser in the catalog department of the Yale University Library, has been appointed head of the department.

Stanley West, recently released from the Navy, has returned to the Columbia University Libraries as assistant law librarian.

Miriam McPherson has been appointed assistant librarian of the State Teachers College at Brockport, N.Y.

James W. Phillips, recently released from the Army, has been named reference librarian of Dickinson College, Carlisle, $\mathrm{Pa}$.

Naomi J. Rushing is now assistant librarian of Miner Teachers College, Washington, D.C.

Marion C. Terry has been promoted to assistant librarian of the State Teachers College at Farmville, Va.

Corinne Bass, formerly on the staff of the Cossitt Library, Memphis, Tenn., has ac- 
cepted the position of librarian of the school of law and instructor in law at the University of Mississippi.

Henrietta Howell has left the Descriptive Cataloging Division of the Library of Congress to become head cataloger at the University of Cincinnati.

Kent Underhill Moore, recently released from the Army, has been appointed head of the cataloging department at Kenyon College, Gambier, Ohio.

Thomas F. Gardner, until recently supervising librarian in circulation of Teachers College, Columbia University, is now assistant librarian and instructor in library science at Kent State University, Kent, Ohio.

Harry T. Dewey, assistant reference librarian of the Engineering Societies Library, New York City, has been appointed chief cataloger at John Crerar Library, Chicago.

Wilmer $\mathrm{H}$. Baatz has been appointed assistant librarian in charge of service and instructor in library science at Beloit College, Beloit, Wis.

Helen Northup has been named associate reference librarian and bibliographer of the University of Wisconsin.

R. Webb Noyes has been appointed librarian of Northland College, Ashland, Wis. $\mathrm{He}$ was formerly librarian of the Maxwell Graduate School of Citizenship and Public Affairs, Syracuse University.
Thomas S. Harding, recently released from the $\mathrm{Navy}$, is the new librarian of $\mathrm{M}$ issouri Valley College, Marshall.

Helen Baird, former instructor in library science at Our Lady of the Lake College, San Antonio, has been appointed assistant librarian of the Abbey Library of St. Benedict's College, Atchison, Kan.

A. S. Gaylord, Jr., is now librarian of the Texas Technological College at Lubbock.

Martin Schmitt, recently released from the Army, is now associate librarian of the University of Idaho.

Mary Elizabeth Bradfield, ex-Navy, is now librarian of the Bancroft Library of the University of California at Berkeley.

Eva Louise Olson, recently released from the WAC, has been appointed librarian of the Biology Library, University of California at Berkeley.

Pauline Calendine, former documents librarian at the State Library of Washington, Olympia, is now documents and periodicals librarian at Reid College, Portland, Ore.

Allan R. Laursen, acting librarian of Knox College, Galesburg, Ill., has been appointed librarian of Pacific University, Forest Grove, Ore.

John S. Mehler, ex-Army, has been appointed librarian of the University of Alaska at Fairbanks.

\section{Retirements}

$\mathrm{M}^{\prime \prime}$ Rs. John A. Goodwin, the former Fanny A. Coldren, reference librarian on the Los Angeles campus of the University of California, has retired after twenty-three years with the university library.
Mary Torrance, head of the catalog department and assistant librarian of the Emory University Library, Emory, Ga., has retired after twenty-two years of service with the university.

$I^{T}$

T IS THE POLICY of College and Research Libraries to print personnel items in the college, university, and research library field that are of general interest. The major source of supply for such items are the reporters of "News from the Field." As the staff of reporters does not remain constant, we frequently fail to receive news from important areas.

The Personnel Editor earnestly solicits information on appointments, retirements, and deaths from administrators and staff members of colleges and universities, deans of library schools, and interested members of the association. Address contributions to the Office of the Editor, Columbia University Libraries, New York City 27. 
The four thousandCollections and Gifts volume private library of important Americana which the late David Wheeler Hazen spent nearly forty years acquiring has been donated to the University of Portland Library by his widow. Included in the collection are approximately five hundred volumes about Abraham Lincoln. The library has received two additional gifts during the year, one of $\$ 3000$ for a purpose to be announced and another of $\$ 1300$ from Edgar J. Daly, of Portland, to establish a library building fund.

The New York State Library recently received a copy of the rare Hudson edition of Washington's Farewell Address from Mrs. Mable Hunt, of Indian Lake, N.Y., who was prompted to make the gift by the newspaper story of the Washington-Lincoln exhibit in the rotunda of the state education building. The volume, which is in its original binding, was printed in Hudson by A. Stoddard in 1797. It has been added to the exhibit, which includes Washington's original manuscript of the Farewell Address.

The memorial book fund was initiated at the Oregon State College Library in 1944-45 with a gift of $\$ 100$ from D. W. Porter, of Palo Alto, for books in memory of his son. A group of alumni raised $\$ 160$ through the Friends of the Library of Oregon State College in honor of R. J. Nichols, librarian from 1902 to 1908 , and other additions brought the total fund to $\$ 750$ by April 1946. A special bookplate gives the name of the donor and the person commemorated, with an additional gold star for the military personnel who have died in service.

The library of Simpson College, Indianola, Iowa, has received most of the private library of a former president, John L. Hillman. It is of special value to a Methodist institution. A gift of five hundred dollars from the Meth-

Note: Reporters who actually contributed to this issue of "News from the Field:" Mrs. Lois B. Payson, librarian, Montana State College Library, Bozeman; Alfred D. Lindsay, associate librarian, New York University: F. B. Streeter, librarian, Fort Hays Kansas State College, Hays; Mrs. Sarah S. Edwards, reference librarian, State University of Iowa Libraries, Iowa City; Wayne S. Yenawine, librarian, Air University, Maxwell Field, Ala.; Charlotte Anne Thompson, librarian, University of Tampa, Tampa, Fla.; Georgia Couch, periodicals librarian, Temple University, Phila delphia; Charles M. Adams, librarian, Woman's College of the University of North Carolina, Greensboro; John VanMale, librarian, University of South Carolina, Columbia; Miss Christian R. Dick. librarian, University of Southern California, Los Angeles.

\section{News from}

odist Board of Education and another of the same denomination from an anonymous friend were also received during the year.

A few years ago, H. J. Thornton, a member of the history faculty of the State University of Iowa, began collecting correspondence, programs, journals, and other material on the Chautauqua movement in the Middle West. More than a dozen theses dealing with local Chautauquas in Iowa and neighboring states have since been written by graduate students using this material. Various persons connected with the Chautauqua movement have offered to hand over their materials if a proper place could be found for their safekeeping. With the cooperation of Ralph Eugene Ellsworth, director of libraries, arrangements have been made whereby the material will be housed in the State University of Iowa Library. Among the collections are those of the late Keith Vawter, director of the Vawter Redpath Bureau of Cedar Rapids; of Harry Harrison whose material from the Redpath Bureau of Chicago filled three hundred packing cases; and the small remaining part of Charles Horner's collection from the Redpath Bureau of Kansas City. Some material has also been received from the International Lyceum Association of Chicago. The library of the State University of Iowa thus becomes headquarters for material on the Chautauqua movement in the Middle West.

Many autographed letters of Theodore Dreiser and first editions of his works have been added to the University of Pennsylvania Library. This is now the most important collection of Dreiseriana in existence.

At the Emory University Charter Day banquet on January 25, Sterling G. Brinkley, secretary-treasurer of the Class of 1907 , presented a check for $\$ 150$ to the university librarian. Since 1938 the members of this class have made a yearly donation to the library. This gift brings their total contribution to more than $\$ 3000$, and 481 volumes now bear the special 1907 gift plate.

The senior medical class at the University of Utah raised approximately seven thousand dollars during $1945-46$ for the university library. The library also received five thousand 


\section{the Field}

dollars for a collection of books to be named in honor of Milton Bennion, dean emeritus of education, and Esther Nelson, librarian emeritus.

Recent gifts to the Library of the Florida State College for Women include 1200 volumes in the fields of history, philosophy, and science from Mrs. H. E. Bierly in memory of her husband who was formerly a professor at the college; a collection of 24 volumes presented by the family of the late $\mathrm{Mr}$. and Mrs. T. E. Byrd of Tallahassee, including works of Washington and Franklin, a Biographical Souvenir of Georgia and Florida, and the I785 Harrison edition of Samuel Johnson's Dictionary of the English Language; and a collection of authoritative works on Jewish history and religion from the Jewish Chautauqua Society of Cincinnati.

Davidson College Library is building up through gifts a considerable collection of $\mathrm{Pe}$ ter Stewart Ney (d. 1846) manuscripts and relics. Regardless of the identity of this mysterious Frenchman in North Carolina (believed by many to have been Napoleon's Marshal Ney in hiding), he is of interest to Davidson College because he designed the official seal of the college.

Salem College Library has received a gift in memory of Mary Duncan McAnally, associate librarian, who was given leave of absence in 1943 to serve as an Army librarian and who died while serving in this capacity on the island of Oahu in July 1945. Miss McAnally had been interested in expanding the microfilm equipment of the library. The gift includes, in addition to a portrait of Miss McAnally, a Recordak reader and a substantial fund for use in the acquisition of microfilm and other needed equipment.

The Library of the Woman's College of the University of North Carolina has recently received one hundred dollars to purchase books on China in memory of Constance Lam of the Class of 1933. During the war Miss Lam becarne director of a camp of two thousand refugee Chinese girls, in addition to teaching classes of children and supervising handwork classes for adults. Later when the city of Hongkong fell to the Japanese, she was permitted to devise whatever relief was possible for the internees. This gift will serve as a memorial to the outstanding work and leader- ship of Miss Lam and will be a permanent memorial to China's culture of which she was so proud.

The Templana Room was opened in the Sullivan Memorial Library at Temple University on February I2. The Conwellana and Templana collections, which are the printed sources for the history of Temple University and the biography of its founder, Russell $\mathrm{H}$. Conwell, are housed in the room. All friends of the university are urged to contribute any material they may possess to make the collections as complete as possible.

$A$ reading and humanities room was opened at the beginning of the spring quarter at Oregon State College Library in space which had been used for storage during the period of decreased enrolment. One of the most accessible and attractive rooms in the building, it contains a selected browsing collection on low shelves, with the balance of the space occupied by the books classified as literature. Seating capacity is provided for seventy-five readers.

At the Ursinus College Library a well-furnished, soundproof room to be used as a combination music and treasure room has been opened. A collection of phonograph records of classical music, donated by Henry Charlton Beck, Jr., and Sarah Hatton Beck in memory of their father, and the William A. Grubb collection, a gift of books in especially fire bindings which came to the library several years ago, are housed in the room. Miss Beck's large personal collection of records has also been placed in the room. Additional gifts will be made from time to time by Miss Beck and her brother, and it is expected that other gifts, particularly from interested students, will follow.

\section{Publications}

The first issue of the Newsletter of the Junior College Libraries Section of the Association of College and Reference Libraries, American Library Association, to be published under the recently appointed newsletter committee, appeared in March. The Newsletter, which goes to all members of the Junior College Libraries Section, is edited by Mrs. Eloise Lindstrom, Stephens College, Columbia, Mo. Contribu- 
tions of news items on activities, publications, exhibits, building plans, etc., are welcomed.

The Library of the Florida State College for Women, Tallahassee, is again publishing its informative and interesting bulletin, Calling All Readers. The bulletin contains material on various services and facilities of the library, short reviews of new books, and miscellaneous data.

"Dissertations, Theses and Papers of the Graduate Library School, University of Chicago, 1930-1945; A Bibliography," compiled by Dorothy Charles, is a presentation of the research work which has been produced during a fifteen-year-period at the Chicago school. The 132 titles represent investigations in which practicing librarians and teachers may find considerable use. The Graduate Library School is willing to loan any title on proper application; if a microfilm copy is desired the school will obtain the requisite permission of the author.

Among theses completed at the Graduate Library School, University of Chicago, during I945 which are of interest to college librarians are the following: Thelma Andrews, "Trends in College Library Buildings;" Minnie R. Bowles, "Library Activities for the Stimulation of Reading among College Students;" Celia Hauck, "A Study of Low-Cost Books;" Sister Mary Rose Warburton, "The Attitude of the Educator towards the College Library."

The North Texas Regional Union List of Serials, Supplement, January 15, 1945February 15, 1946, is a mimeographed 133page volume intended to bring up to date the original list (1943) and the first supplement (1945). The present volume gives evidence of the efforts that are being made to fill the gaps in the files held in the region. Arthur M. Sampley, North Texas State Teachers College, Benton, is editor.

Two recent studies of importance to librarians and educators are the Mississippi Study of Higher Education, 1945 by Joseph E. Gibson, director, and others, and Public Higher Education in South Carolina, A Survey Report (1946), made by the Division of Surveys and Field Services, George Peabody College for Teachers.

The American Russian Institute, 58 Park Ave., New York City, has issued in mimeographed form the Special Libraries Confer- ence on Russian Materials, November 17 , 1945. The conference is the first coordinated attempt of special libraries handling Russian materials to pool their experiences, with the eventual aim of enlarging the resources on the subject. Copies of the report are available from the institute at $\$ 2.50$ per copy.

Jewish Social Studies has issued a special supplement, vol. 8, no. I, 1946, entitled Tentative List of Jewish Cultural Treasures in Axis-Occupied Countries. The list includes only movable treasures, such as books, documents, or museum pieces.

A publication of interest to college and reference librarians is Research in Public Administration by William Anderson and John M. Gaus (Public Administration Service, 1945). The volume considers such aspects as major research projects, capturing and recording administrative experiences, case reports in public administration, general planning and promotion of research, and other matters connected with the Committee on Public Administration. Essentially, the book is a report of this committee to the Social Science Research Council. Insofar as the work of the council is made up of the work of its committee, it is also a report of the council.

The second edition of the Philadelphia Regional Catalogers' Group Directory of Catalogers of the Philadelphia Area has been announced. Copies are obtainable for 30 cents from the secretary, Mary A. Crozer, University of Pennsylvania Library, Philadelphia 4.

Certain publications of the Royal Bank of Canada are available for free distribution to libraries and individuals who wish to complete their files. All copies not requested will be destroyed and the publications will then be out of print. Inquiries and requests should be addressed to Mildred I. Turnbull, librarian, Royal Bank of Canada, Montreal I, P.Q.

The Feb. I, 1946, issue of Higher Education contains an article by Robert R. Hudelson on the "University of Illinois Future Programs," while the February 15 issue includes "Development of the United States Office of Education" by John W. Studebaker.

The U.S. Office of Education has published its annual report for the year ending June 30, 1945. In the section devoted to higher education the report refers to the emphases on research, curriculum construction, and 
teaching anticipated in assisting colleges to repair the effects of the war and in meeting new problems arising in the postwar years. Among other sections one is devoted to the activities of the office in the field of library service. Copies of Annual Report of the Federal Security Agency, Section Two, U.S. Office of Education, 1945, are I 5 cents each, from the Superintendent of Documents, U.S. Government Printing Office, $W$ ashington 25, D.C.

Proposals Relating to the Statistical Function of the U.S. Office of Education, a Report of the National Conference on the Office of Education Statistical Program (Bulletin I 946 , No. 2), can be obtained from the Superintendent of Documents, U.S. Government Printing Office, Washington 25, D.C., for 10 cents.

Document librarians will be interested in knowing of Documents Office Classification, a compilation of the classification numbers used in the Office of the Superintendent of Documents, by Mary Elizabeth Poole, reference and document librarian of North Carolina State College. It is available at \$10.40 in a loose-leaf, lithoprinted edition (notebook not included) and includes Superintendent of Documents' numbers through August 1945, arranged in shelflist order. The information given in each case is the entire number, the name of the class or particular series, frequency (if regular and known), format (if processed), and references to earlier and later classifications. No dates are given for individual publications, but, where obtainable, the dates and statutory authority are given for the origin and termination of agencies. In the index, bureaus are listed under their own name and under the name of their department.

The Library of Congress in collaboration with two publishers is sponsoring a series, European Imprints for the War Years Received in the Library of Congress and Other Federal Libraries, which is intended to provide a checklist of wartime titles both as a finding list for use in research and as a tool for ordering work in libraries. The first part of the series, Italian Imprints, 19401945, has been published by G. E. Stechert, New York City. It lists approximately 7,500 titles, principally monographic, now available in the federal libraries. The second volume, German Imprints, 1940-1945, published by
J. W. Edwards, Ann Arbor, Mich., lists approximately $\mathrm{I} 3,000$ principally monographic titles, all now held in Washington libraries. A third volume, listing French imprints, 1940-I945, will also be published.

The Final Report of the New York State Joint Legislative Committee on Legislative Methods, Practices, Procedures and Expenditures (1946) contains extensive references to library services. The report is of special interest to librarians in that it sets a new standard in legislative research.

\section{Microfilms}

University Microfilms, Ann Arbor, Mich., released the first one hundred thousand pages of its new series in June. The first series was commenced in I94I to make available on microfilm all known, extant, and available periodicals published in the United States between I74I and I799. The new series continues the project through the years $1800-25$, the first one hundred thousand pages covering 1800 to 1809. Libraries may purchase any or all of the following periods: I800-09, I810-19, 1820-25. It is expected that it will take five years to complete the entire project, but film will be distributed as each title is completed. About one hundred thousand pages will be completed each year at an annual cost of \$450. A catalog locating each title on each one hundred-foot reel and catalog cards will accompany the set. The film series are designed to meet the needs of the scholar and research worker and make it possible for the first time for any library to acquire important early source materials at a lower cost per page than is paid for many current publications.

During the war the Aslib Microfilm Service made available microfilm and paper enlargements of scientific and technical periodicals from enemy and enemy-occupied countries which would not otherwise have been generally accessible to research workers. The end of the war reduced the demand for this special function but made apparent the need for rehabilitation of medical libraries. By arrangement with the Royal Society of Medicine, and with the consent of the Rockefeller Foundation and the Royal Society, it has been agreed that the equipment hitherto used by Aslib should be transferred to the 
use of a special medical microfilm service, and on January I the Aslib Microfilm Service became the Central Medical Library Bureau of the Royal Society of Medicine. Aslib will still be able to arrange for the supply of photographic copies of certain types of literature. The A.M.S. library of master-films of scientific and technical periodicals contains some fourteen thousand issues of several hundred titles published during the war years of which a cumulative list is available. To save time and labor, not less than whole issues of the journals in the cumulative list will be supplied in microfilm in the future; orders for individual papers will be executed in paper enlargements. All orders, including requests for copies of individual references from varied literature, should be addressed to Aslib, 52 Bloomsbury St., London WCr.

A gift of $\$ 200,000$ Buildings and Plans toward the new library building at Bucknell University was announced at the midwinter commencement held March 4. The name of the donor was not made public. This gift and previously announced contributions of $\$ 175,000$ bring the university's library fund to $\$ 375,000$. The new building will cost approximately $\$ 500,000$.

Mrs. J. H. Crosland, librarian of the Georgia School of Technology, has completed preliminary plans for a new library building to be a central wing of a large administration and academic building. The library wing, to cost approximately $\$ 800,000$, will greatly increase the service areas for students and faculty and will provide open shelves and bookstacks for five hundred thousand volumes.

The Abbey Library, St. Benedict's College, Atchison, Kan., has ordered additional steel stacks to shelve fifteen thousand volumes and is making plans for a new library building which will cost about $\$ 300,000$.

Western Union College Library, Le Mars, Iowa, is making a drive for $\$ 125,000$ for a new library building. The present collection of fifteen thousand volumes is being augmented rapidly by purchase and gift.

A contract has been let for the building of a fourth tier of stacks, to house twenty-five thousand volumes, for the library at Luther College, Decorah, Iowa. The collection, which consisted of twenty-five thousand volumes when the present building was erected in 1920 , has now reached a total of eighty thousand.

New York University School of Law has announced a proposed new building for construction at $\mathrm{W}$ ashington Square. Preliminary subscriptions have reached nearly $\$ 46,000$, over 70 per cent paid in.

New York University has announced plans for construction of a $\$ 15,000,000$ medical center, adjoining the area of the present Bellevue Hospital, the latter to be rebuilt by the City of New York at a cost of $\$ 12,500,000$. The combined project will occupy nine city blocks. The university area will include a new college of medicine building, a university clinic, a university hospital, a hall of residence for medical students, an auditorium, and an institute of forensic medicine. At the opening campaign dinner, advance contributions of $\$ 122,000$ were reported, and an additional $\$ 6$ i5,000 has been raised toward the $\$ 750,000$ goal for the hall of residence.

\section{Fellowships}

Michigan State College Library offers a half-time assistantship for the academic year 1946-47 to an experienced librarian with a full year of library training who will work for a master's degree. The stipend, fixed by the college for half-time assistantships, is $\$ 800$ for twenty hours of work a week for ten months. The candidate may choose his own field in which to work for the M.S., M.A., M.Music, M.Forestry, or a professional degree in engineering. A curriculum is available for county and rural librarians in rural sociology. A transcript of credits and record of experience should be sent with letters of application to Jackson E. Towne, librarian, Michigan State College, East Lansing.

The organization American Book Center and functions of the American Book C'enter for War Devas-

tated Libraries were briefly described in the April issue of College and Research Libraries. A further announcement from the center makes clear their present needs. It is probable that much of the material sent abroad will go to national, university, and college 
libraries. Scholarly works useful in research and for rehabilitation of war-ravaged areas are wanted. Emphasis is placed on books and periodicals of a scientific and technical nature or which are standard in their fields, and particularly those published in the last ten years. Light fiction, material of purely local interest, most textbooks, and popular magazines are not needed. Federal, state, and local documents dealing with such subjects as municipal planning, public health, medicine, etc., will be very useful abroad, but it is suggested that a description of the documents available should be sent to the office before the documents are shipped. All shipments should be sent prepaid to the American Book Center, c/o the Library of Congress, Washington 25, D.C. The center hopes that donors will assume the costs of transportation but when this is not possible reimbursement will be made upon notification of the amount due.

\section{Exhibits}

The University of California Library at

Los Angeles opened an exhibition of typography, books, and printing by Grant Dahlstrom on Mar. 25, 1946. Since $1943 \mathrm{Mr}$. Dahlstrom has owned the Castle Press at Pasadena.

An exhibition of unusual importance at the University of Pennsylvania Library is a collection of Nazi schoolbooks from a village in the Black Forest and typical of the party's educational methods. It clearly shows the many devices used to influence the young German mind.

An exhibition of water colors by Stanley Corneal was put on display in the Templana Room at Temple University when the room was opened on February 15.

The Library of the University of North Carolina has had on display a large and colorful exhibit drawn from the Bowman Gray Collection of World War I materials. This very extensive collection of books, pamphlets, posters, maps, photographs, documents, and periodicals, some of them unique, offers to historians a remarkably complete source for studying the various ways of influencing public opinion employed by both the Allied and the Central powers in the years from 1914 to I920.

The fourth National J. and E. R. Pennell
Exhibition of Prints, which was opened at the Library of Congress on May I, included engravings, etchings, wood engravings, block prints, lithographs, and serigraphs of 296 artists. Thirty purchase prizes were awarded by the Standing Committee for the Purchase of Prints on the Pennell Fund.

During April and May an exhibition of a collection of first editions of James Fenimore Cooper, a gift of Leonard Kebler, was held in the Columbia University Library.

\section{A library institute, Courses, Curricula, sponsored by Western Conferences Reserve University School of Library} Science and the Ohio State Library, will be held at Western Reserve University, Cleveland, from July 8 through July 20. Carl Vitz, librarian of the Cincinnati Public Library, will open the institute with an address on "The Public Library of Today and Tomorrow." Both children's library service and adult library activities will be emphasized with sessions devoted to children's literature and basic principles in its selection, the library as a central information office for the community, new developments in librarycommunity activity, and trends in adult book publication in 1945-46. The program for three afternoons will include a practical library clinic. The fee for the course is \$10. Registration will be held July 6 and July 8 in the School of Library Science, Thwing Hall, I I I I Euclid Avenue, Cleveland.

The Rock River Community College, an evening school of the liberal arts, was opened as a community service by Beloit College, Beloit, Wis., in March. Classes in literature, government, art, dramatics, music, and other subjects met weekly from March 4 to May 9. Courses were planned to interest men and women regardless of their previous formal education and credit was not offered, classes being open to all upon payment of a small fee.

The "New Plan of Study for the Bachelor of Arts Degree at Princeton" is described by E. Harris Harbison in the March $I$ issue of Higher Education. The necessity for both general and special education, the relationship of the two, and Princeton's plan for a four-year progression from general to specialized study with requirements to meet these needs are discussed. 
The second short training course in the preservation and administration of archives for custodians of public, institutional, and business archives, was offered by the American University in Washington, D.C., with the cooperation of the National Archives and the Maryland $\mathrm{Hall}$ of Records from June $\mathrm{I} 7$ through July 6, 1946. The program provided lectures on the most important phases of archival administration and practical work in such fields as arrangement and description of archives, repair and preservation, cataloging, calendaring, and photoduplication.

The State Teachers Colleges of Pennsylvania at Millersville and Kutztown are sponsoring jointly an annual school library conference for eastern Pennsylvania. This year it was held at Kutztown on April 5 and 6. In 1947 the conference will be held at Millersville on March 7 and 8.

The World Congress on Air-Age Education will be held August 2I-28 at International House, in New York City, for the purpose of considering how aviation may contribute to a peaceful and united world.

At the final convocation of the sesquicentennial celebration of the University of North Carolina on Apr. 13, 1946, the Library of Congress was represented by Lewis Hanke, the American Library Association by Charles
M. Adams, the Bibliographical Society of America by Charles E. Rush, the Association of College and Reference Libraries by Olan $V$. Cook, the Huntington Library by $W$. Dougald MacMillan, the state library commission by H. Marjorie Beal, and the North Carolina Library Association by Susan Grey Akers. On this occasion a doctor of letters was awarded to Joseph Quincy Adams, director of the Folger Shakespeare Library.

The Bull's Head Bookshop, in the University of North Carolina Library, makes a custom of presenting a local author at a tea each month. Those who have spoken at the teas this year are Betty Smith, author of $A$ Tree Grows in Brooklyn. James Street, of The Gauntlet, and Noel Houston, of The Great Promise. The final speaker this season was Thomas Tileston Waterman, whose Mansions of Virginia was published by the University of North Carolina Press on April 27.

An undergraduate library committee has been formed at the University of Pennsylvania to meet with library officials at frequent intervals. This committee, as well as the graduate student library committee, brings up matters of importance to the student body. It is hoped that close cooperation will make possible a more effective service. 